\title{
Lack of PRAME Expression in Cutaneous T-Cell Lymphomas
}

\author{
Chau M. Bui ${ }^{1, *}$, Sumire Kitahara ${ }^{1}$, Wonwoo Shon ${ }^{1} \mathbb{(}$, Tatsiana Pukhalskaya ${ }^{2}$ and Bruce R. Smoller ${ }^{2} \mathbb{C}$ \\ 1 Department of Pathology and Laboratory Medicine, Cedars Sinai Medical Center, \\ Los Angeles, CA 90048, USA; sumire.kitahara@cshs.org (S.K.); wonwoo.shon@cshs.org (W.S.) \\ 2 Department of Pathology and Laboratory Medicine, University of Rochester Medical Center, \\ Rochester, NY 14642, USA; Tatsiana_Pukhalskaya@URMC.Rochester.edu (T.P.); \\ Bruce_Smoller@URMC.Rochester.edu (B.R.S.) \\ * Correspondence: chau.bui@cshs.org; Tel.: +1-310-423-3426
}

check for updates

Citation: Bui, C.M.; Kitahara, S.; Shon, W.; Pukhalskaya, T.; Smoller, B.R. Lack of PRAME Expression in Cutaneous T-Cell Lymphomas. Dermatopathology 2022, 9, 11-16. https://doi.org/10.3390/ dermatopathology 9010002 Academic Editor: Gürkan Kaya

Received: 6 December 2021 Accepted: 29 December 2021 Published: 31 December 2021

Publisher's Note: MDPI stays neutral with regard to jurisdictional claims in published maps and institutional affiliations.

Copyright: (C) 2021 by the authors. Licensee MDPI, Basel, Switzerland. This article is an open access article distributed under the terms and conditions of the Creative Commons Attribution (CC BY) license (https:// creativecommons.org/licenses/by/ $4.0 /)$.

\begin{abstract}
Cutaneous T-cell lymphomas (CTCLs) are rare tumors with no established markers that can reliably distinguish between benign and malignant lesions. Preferentially Expressed Antigen in Melanoma (PRAME) is a cancer/testis antigen that is found in many solid and hematologic malignancies. PRAME overexpression typically portends a poor prognosis and lower chemotherapeutic response. To date, no studies have established a role for PRAME in CTCL. An analysis was performed on 47 cases definitively diagnosed as CTCL: 25 cases of mycosis fungoides, 2 of Sezary syndrome, 5 of CD30+ lymphoproliferative disorder, 7 of primary cutaneous anaplastic large T-cell lymphoma, 3 of primary cutaneous CD4+ small/medium T-cell lymphoproliferative disorder, 1 of subcutaneous panniculitis-like T-cell lymphoma, and 4 of angiocentric T-cell lymphoma. PRAME immunohistochemistry was completely negative in all cases. PRAME expression was not found in any CTCL subtypes, suggesting that the pathogenesis of CTCL is not mediated by PRAME. Further study is required to identify biomarkers that might aid in the diagnosis and prognostication of CTCLs.
\end{abstract}

Keywords: PRAME; cutaneous T-cell lymphoma

\section{Introduction}

Cutaneous T-cell lymphomas (CTCLs) are a rare class of tumors with an annual incidence of approximately 0.5 in 100,000 [1]. Mycosis fungoides (MF) is the most common form of CTCL, accounting for between $44 \%$ and $62 \%$ of all CTCLs [2]. While most subtypes of CTCL have an indolent clinical course, there are a number of more aggressive variants that have a very poor prognosis. The diagnosis of MF and other CTCLs can be difficult and requires a combination of the clinical examination, histopathologic evaluation, immunophenotyping, and molecular analysis [3-13]. To date, there are no established molecular markers that can reliably be used to diagnose malignant $\mathrm{T}$ cells found in a suspicious skin lesion or to distinguish aggressive from indolent CTCL subtypes. Polymerase chain reaction (PCR) and next generation sequencing (NGS) can be used to identify a clone of $\mathrm{T}$ cells expressing an identical rearranged copy of the T-cell receptor (TCR) gene, but these tests may fail to identify early-stage lesions $[3,14,15]$. A method that uses immunohistochemistry (IHC) to assist diagnosis and predict prognosis would have great clinical utility, given the superior turnaround time and cost effectiveness with IHC as compared to molecular testing.

Preferentially Expressed Antigen in Melanoma (PRAME) is a cancer/testis antigen (CTA). The CTA family comprises a number of genes whose expression is typically restricted to only male germ cells. These antigens are abnormally re-expressed in a variety of solid and hematologic malignancies [16-30]. PRAME overexpression is believed to prevent cell cycle arrest and apoptosis by inhibiting the retinoic acid signaling pathway. However, the molecular functions of PRAME in tumor cells remain largely unknown and may differ among different tissue types. Many studies have reported that PRAME is 
a helpful marker to distinguish between malignant melanoma and benign nevi. PRAME overexpression generally portends a poor prognosis with shorter overall survival and progression-free survival [22-25,28,31-34]. Due to its highly restricted pattern of expression, PRAME has emerged as an attractive target for cancer immunotherapy, in which cytotoxic T lymphocytes are developed to selectively target and eliminate PRAME-positive cancer cells $[21,35-38]$.

To date, no studies have established a role for PRAME in the diagnosis and prognosis of CTCLs. We hypothesized that PRAME might be a useful marker to assist in the diagnosis of CTCLs and to differentiate between indolent and aggressive lesions.

\section{Materials and Methods}

This is a retrospective analysis utilizing pre-existing tissue from patients with a definitive diagnosis of CTCL by biopsy. For MF in particular, tumors at either the patch stage or more advanced stages (plaque and tumoral) were included. Patients younger than 18 years old or with concomitant malignancy of the skin at other sites were excluded. Specimens were obtained from the surgical pathology archive of a tertiary medical center over a 10-year span. Unstained recuts were obtained from the original formalin-fixed paraffin-embedded tissue (FFPET) blocks. Hematoxylin and eosin (H\&E) staining and immunohistochemistry for PRAME (EPR20330 rabbit monoclonal antibody) with red chromogen were performed on recut slides.

All cases were reviewed by two independent investigators to confirm the diagnoses and evaluate PRAME expression. The following parameters were evaluated: percentage of PRAME expression, nuclear/cytoplasmic expression, and intensity and extent of staining. Melanoma and sebaceous glands were used as external and internal positive controls, respectively. The results were tabulated and compared utilizing statistical software in Excel and SPSS. A chi-squared test was used to compare differences in PRAME expression between malignant $\mathrm{T}$ cells in CTCL and adjacent normal sebaceous glands or melanoma tissue as a control group.

\section{Results}

The study consisted of 47 CTCLs from patients aged 26 to 91 years with an average age of 59.2, with 31 male $(66.0 \%)$ and 16 female $(34.0 \%)$ patients. There were 28 white $(59.6 \%)$, 8 black $(17.0 \%), 2$ Asian (4.3\%), 2 other non-Hispanic (4.3\%), and 7 patients of unknown ethnicity $(14.9 \%)$.

The sample included 25 cases of mycosis fungoides (53.2\%), 2 of Sezary Syndrome (4.3\%), 5 of CD30+ lymphoproliferative disorder (10.6\%), 7 of primary cutaneous anaplastic large T-cell lymphoma (14.9\%), 3 of primary cutaneous CD4+ small/medium T-cell lymphoproliferative disorder $(6.4 \%)$, 4 of angiocentric T-cell lymphoma (also known as extranodal NK/T-cell lymphoma, nasal type) (8.5\%), and 1 of subcutaneous panniculitis-like T-cell lymphoma (2.1\%). Of the $25 \mathrm{MFs}$, all stages (patch, plaque, and tumoral) were represented, including 3 cases with large cell transformation (12.0\%), 2 with the CD8 immunophenotype $(8.0 \%)$, and 1 with blast cell transformation (4.0\%). PRAME immunohistochemical staining was strongly and diffusely positive in both the external positive control-melanoma tissue - and the internal positive control — benign sebaceous glands, whereas the stain was completely negative in all malignant $\mathrm{T}$ cells (Table 1, Figure 1). The background cells, including reactive lymphocytes, were also negative for PRAME in all cases.

Table 1. PRAME immnohistochemistry in CTCLs.

\begin{tabular}{ccc}
\hline CTCLs & $\begin{array}{c}\text { Number of } \\
\text { Cases (\%) }\end{array}$ & $\begin{array}{c}\text { PRAME } \\
\text { Immunohistochemistry }\end{array}$ \\
\hline MF & $25(53.2)$ & Negative \\
MF with CD8 immunophenotype & $2(8.0)$ & Negative \\
MF with large cell transformation & $3(12.0)$ & Negative \\
MF with blast cell transformation & $1(4.0)$ & Negative \\
\hline
\end{tabular}


Table 1. Cont.

\begin{tabular}{ccc}
\hline CTCLs & $\begin{array}{c}\text { Number of } \\
\text { Cases (\%) }\end{array}$ & $\begin{array}{c}\text { PRAME } \\
\text { Immunohistochemistry }\end{array}$ \\
\hline $\begin{array}{c}\text { Sezary Syndrome } \\
\text { CD30+ lymphoproliferative disorder }\end{array}$ & $2(4.3)$ & Negative \\
Primary cutaneous anaplastic large & $5(10.6)$ & Negative \\
T-cell lymphoma & $7(14.9)$ & Negative \\
Primary cutaneous CD4+ small/medium T-cell & $3(6.4)$ & Negative \\
Lymphoproliferative disorder & $4(8.5)$ & Negative \\
Angiocentric T-cell lymphoma & $1(2.1)$ & Negative \\
Subcutaneous panniculitis-like T-cell lymphoma & &
\end{tabular}
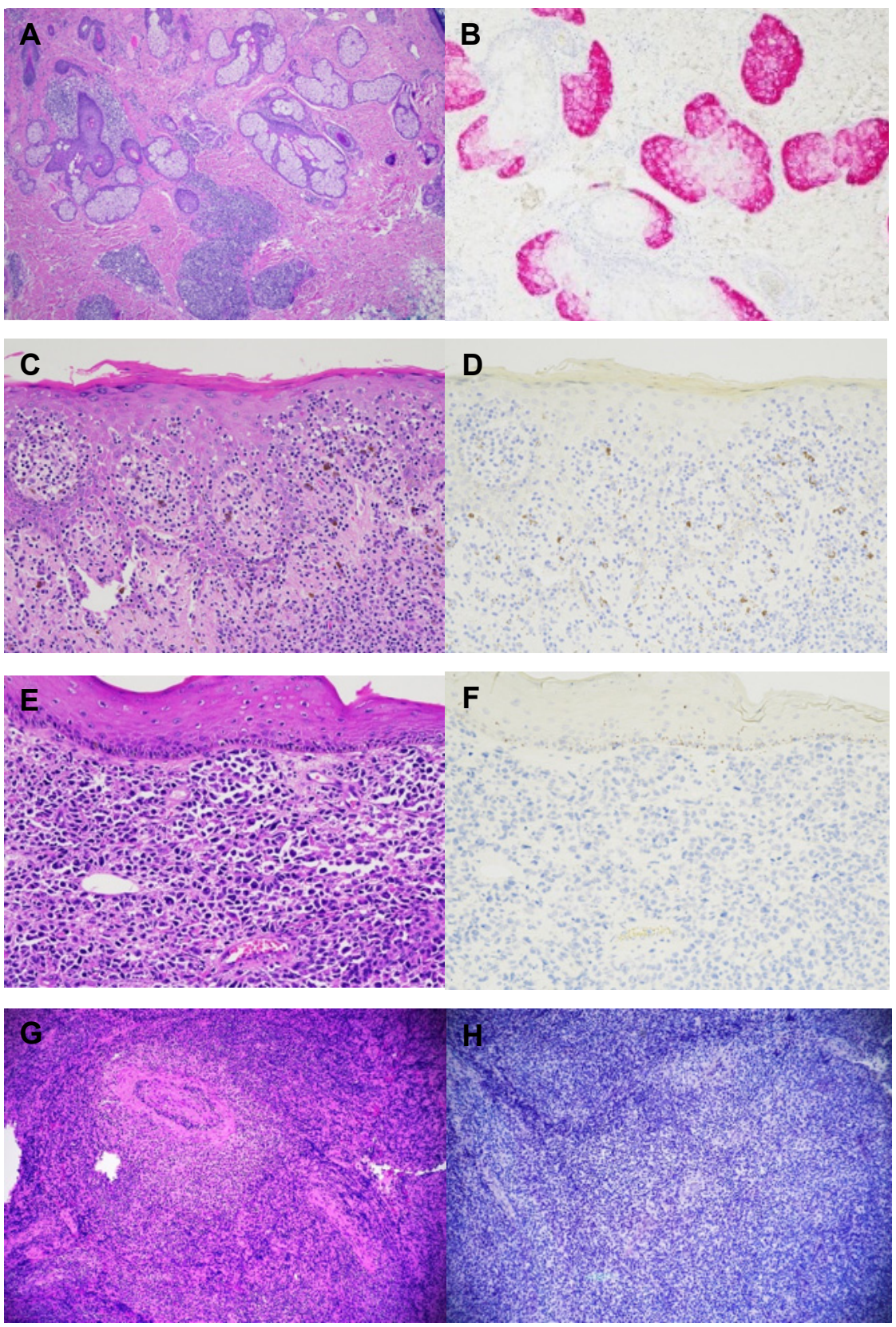

Figure 1. (A,B). H\&E and PRAME stain of primary cutaneous small/medium CD4+ T-cell lymphoproliferative disorder with normal sebaceous glands (internal positive control), (C,D). H\&E and PRAME stain of MF, (E,F). H\&E and PRAME stain of primary cutaneous anaplastic large cell lymphoma, $(\mathbf{G}, \mathbf{H})$. H\&E and PRAME stain of angiocentric T-cell lymphoma. 


\section{Discussion}

The function of PRAME in normal and tumor cells is not completely understood, although a role in the regulation of retinoic acid signaling and immune evasion has been proposed. The regulation of PRAME gene expression is also poorly understood, and thus the molecular basis of its expression in malignancies is largely unknown. While PRAME is absent or expressed at very low levels in most normal tissues, high levels of PRAME mRNAs are encountered in certain types of malignant cells. PRAME expression has been described in a variety of hematologic malignancies, including both acute and chronic myeloid and lymphocytic leukemias, hairy cell leukemia, Hodgkin's lymphoma, diffuse large B-cell lymphoma, mantle cell lymphoma, and multiple myeloma. PRAME overexpression in these tumors generally portends a poor prognosis with shorter overall survival and progression-free survival and lower chemotherapeutic response [25-34]. Some studies have described a favorable prognosis with PRAME overexpression in both acute myeloid and lymphoblastic leukemia in pediatric patients as well as acute myeloid leukemia in adults [39-42]. There have been no studies of PRAME expression in either cutaneous or non-cutaneous T-cell lymphoma.

While most cases of CTCL have an indolent clinical course, some subtypes have a very aggressive course. For instance, MF is typically a slow-growing tumor, but a small subset of cases can progress quickly to large cell or blast cell transformation, which is associated with worse prognosis. In 2018, Masson D et al. found that in CTCLs-particularly MFa tumor clone frequency $>25 \%$ (measured by high-throughput sequencing of the TCRB gene) is an independent predictor of early disease progression and death [43]. However, to date, there are no established molecular markers that can be used to reliably predict malignant potential in T cell neoplasms. We hypothesized that PRAME might have value as a molecular "fingerprint" to help with this distinction given its correlation with disease progression in other hematologic malignancies. However, PRAME expression was not found in any of the CTCL lymphoma subtypes assessed in this study, including both indolent $(\mathrm{MF}, \mathrm{CD} 30+$ lymphoproliferative disorder, primary cutaneous anaplastic large T-cell lymphoma, primary cutaneous CD4+ small/medium T-cell lymphoproliferative disorder, and subcutaneous panniculitis-like T-cell lymphoma) as well as aggressive (leukemic MF, Sezary Syndrome, and angiocentric T-cell lymphoma) subtypes.

This study had several limitations that should be acknowledged. Firstly, only one PRAME clone was used in the study; the results may have differed if another clone were used due to variable immunohistochemical staining patterns among different PRAME clones. Secondly, we did not stain all subtypes of CTCLs, with the notable omission of primary cutaneous gamma-delta T-cell lymphoma, primary cutaneous acral CD8+ Tcell lymphoma, and primary cutaneous CD8+ aggressive epidermotropic cytotoxic T-cell lymphoma due to the extreme rarity of these entities. As such, the results of this study cannot be generalized to all subtypes of CTCL.

\section{Conclusions}

In summary, our study suggests that the pathogenesis of CTCL is not mediated by PRAME. Further study is required to identify additional biomarkers that might aid in the diagnosis and prognostication of CTCL.

Author Contributions: Conceptualization, C.M.B. and B.R.S.; methodology, C.M.B. and B.R.S.; formal analysis, C.M.B. and B.R.S.; investigation, C.M.B. and B.R.S.; resources, C.M.B. and B.R.S.; data curation, C.M.B., B.R.S., T.P., S.K. and W.S.; supervision, B.R.S.; writing-original draft preparation, C.M.B.; writing-review and editing, C.M.B., B.R.S., S.K., W.S. and T.P.; visualization, C.M.B. and T.P. All authors have read and agreed to the published version of the manuscript.

Funding: This research received no external funding.

Institutional Review Board Statement: The study was conducted according to the guidelines of the Declaration of Helsinki and approved by the Institutional Review Board of Cedars Sinai Medical 
Center (protocol code: 976 and date of approval: 28 September 2020) and the University of Rochester Medical Center (protocol code: 5114 and date of approval: 23 June 2020).

Informed Consent Statement: Informed consent was waived since consent was already obtained at the time of biopsy.

Data Availability Statement: The data supporting reported results can be found at https:/ / pubmed. ncbi.nlm.nih.gov (accessed on 28 December 2021).

Acknowledgments: Staffs of the Histology and Immunohistochemistry Laboratories of CSMC and URMC.

Conflicts of Interest: The authors declare no conflict of interest.

\section{References}

1. Rodd, A.L.; Ververis, K.; Karagiannis, T.C. Current and Emerging Therapeutics for Cutaneous T-Cell Lymphoma: Histone Deacetylase Inhibitors. Lymphoma 2012, 2012, 290685. [CrossRef]

2. Eklund, Y.; Aronsson, A.; Schmidtchen, A.; Relander, T. Mycosis Fungoides: A Retrospective Study of 44 Swedish Cases. Acta Derm. Venereol. 2016, 96, 669-673. [CrossRef]

3. Bagherani, N.; Smoller, B.R. An overview of cutaneous T cell lymphomas. F1000Res 2016, 5, 1882. [CrossRef] [PubMed]

4. Wilcox, R.A. Cutaneous T-cell lymphoma: 2017 update on diagnosis, risk-stratification, and management. Am. J. Hematol. 2017, 92, 1085-1102. [CrossRef]

5. Willemze, R.; Cerroni, L.; Kempf, W.; Berti, E.; Facchetti, F.; Swerdlow, S.H.; Jaffe, E.S. The 2018 update of the WHO-EORTC classification for primary cutaneous lymphomas. Blood 2019, 133, 1703-1714, Correction in Blood 2019, 134, 1112. [CrossRef]

6. Olsen, E.; Vonderheid, E.; Pimpinelli, N.; Willemze, R.; Kim, Y.; Knobler, R.; Zackheim, H.; Duvic, M.; Estrach, T.; Lamberg, S.; et al. Revisions to the staging and classification of mycosis fungoides and Sezary syndrome: A proposal of the International Society for Cutaneous Lymphomas (ISCL) and the cutaneous lymphoma task force of the European Organization of Research and Treatment of Cancer (EORTC). Blood 2007, 110, 1713-1722, Erratum in Blood 2008, 111, 4830. [CrossRef]

7. Vandergriff, T.; Nezafati, K.A.; Susa, J.; Karai, L.; Sanguinetti, A.; Hynan, L.S.; Ambruzs, J.M.; Oliver, D.H.; Pandya, A.G. Defining early mycosis fungoides: Validation of a diagnostic algorithm proposed by the International Society for Cutaneous Lymphomas. J. Cutan. Pathol. 2015, 42, 318-328. [CrossRef] [PubMed]

8. Peterson, E.; Weed, J.; Lo Sicco, K.; Latkowski, J.A. Cutaneous T Cell Lymphoma: A Difficult Diagnosis Demystified. Dermatol. Clin. 2019, 37, 455-469. [CrossRef]

9. Foss, F.M.; Girardi, M. Mycosis Fungoides and Sezary Syndrome. Hematol. Oncol. Clin. N. Am. 2017, 31, 297-315. [CrossRef]

10. Hodak, E.; Amitay-Laish, I. Mycosis fungoides: A great imitator. Clin. Dermatol. 2019, 37, 255-267. [CrossRef] [PubMed]

11. Pulitzer, M. Cutaneous T-cell Lymphoma. Clin. Lab. Med. 2017, 37, 527-546. [CrossRef] [PubMed]

12. Geller, S.; Myskowski, P.L.; Pulitzer, M.; Horwitz, S.M.; Moskowitz, A.J. Cutaneous T-cell lymphoma (CTCL), rare subtypes: Five case presentations and review of the literature. Chin. Clin. Oncol. 2019, 8, 5. [CrossRef] [PubMed]

13. Cocks, M.; Porcu, P.; Wick, M.R.; Gru, A.A. Recent Advances in Cutaneous T-cell Lymphoma: Diagnostic and Prognostic Considerations. Surg. Pathol. Clin. 2019, 12, 783-803. [CrossRef]

14. Jawed, S.I.; Myskowski, P.L.; Horwitz, S.; Moskowitz, A.; Querfeld, C. Primary cutaneous T-cell lymphoma (mycosis fungoides and Sézary syndrome): Part I. Diagnosis: Clinical and histopathologic features and new molecular and biologic markers. J. Am. Acad. Dermatol. 2014, 70, 205.e1-205.e16. [CrossRef] [PubMed]

15. Kirsch, I.R.; Watanabe, R.; O'Malley, J.T.; Williamson, D.W.; Scott, L.-L.; Elco, C.P.; Teague, J.E.; Gehad, A.; Lowry, E.L.; LeBoeuf, N.R.; et al. TCR sequencing facilitates diagnosis and identifies mature T cells as the cell of origin in CTCL. Sci. Transl. Med. 2015, 7, 308ra158. [CrossRef]

16. Xu, Y.; Zou, R.; Wang, J.; Wang, Z.; Zhu, X. The Role of the Cancer Testis Antigen PRAME in Tumorigenesis and Immunotherapy in Human Cancer. Cell Prolif. 2020, 53, e12770. [CrossRef]

17. Ikeda, H.; Lethé, B.; Lehmann, F.; Van Baren, N.; Baurain, J.-F.; De Smet, C.; Chambost, H.; Vitale, M.; Moretta, A.; Boon, T.; et al. Characterization of an antigen that is recognized on a melanoma showing partial HLA loss by CTL expressing an NK inhibitory receptor. Immunity 1997, 6, 199-208. [CrossRef]

18. Quintarelli, C.; Dotti, G.; Hasan, S.T.; De Angelis, B.; Hoyos, V.; Errichiello, S.; Mims, M.; Luciano, L.; Shafer, J.; Leen, A.M.; et al. High-avidity cytotoxic T lymphocytes specific for a new PRAME-derived peptide can target leukemic and leukemic-precursor cells. Blood 2011, 117, 3353-3362. [CrossRef] [PubMed]

19. Salmaninejad, A.; Zamani, M.R.; Pourvahedi, M.; Golchehre, Z.; Hosseini Bereshneh, A.; Rezaei, N. Cancer/Testis Antigens: Expression, Regulation, Tumor Invasion, and Use in Immunotherapy of Cancers. Immunol. Investig. 2016, 45, 619-640. [CrossRef] [PubMed]

20. Lezcano, C.; Jungbluth, A.A.; Busam, K.J. PRAME Immunohistochemistry as an Ancillary Test for the Assessment of Melanocytic Lesions. Surg. Pathol. Clin. 2021, 14, 165-175. [CrossRef] [PubMed]

21. Wei, R.; Dean, D.C.; Thanindratarn, P.; Hornicek, F.J.; Guo, W.; Duan, Z. Cancer testis antigens in sarcoma: Expression, function and immunotherapeutic application. Cancer Lett. 2020, 479, 54-60. [CrossRef] [PubMed] 
22. Zhu, H.; Wang, J.; Yin, J.; Lu, B.; Yang, Q.; Wan, Y.; Jia, C. Downregulation of PRAME Suppresses Proliferation and Promotes Apoptosis in Hepatocellular Carcinoma Through the Activation of P53 Mediated Pathway. Cell Physiol. Biochem. 2018, 45, 1121-1135, Epub 7 February 2018. [CrossRef] [PubMed]

23. Dyrskjøt, L.; Zieger, K.; Kissow Lildal, T.; Reinert, T.; Gruselle, O.; Coche, T.; Borre, M.; Ørntoft, T.F. Expression of MAGE-A3, NY-ESO-1, LAGE-1 and PRAME in urothelial carcinoma. Br. J. Cancer 2012, 107, 116-122. [CrossRef]

24. Zhang, W.; Barger, C.J.; Eng, K.H.; Klinkebiel, D.; Link, P.A.; Omilian, A.; Bshara, W.; Odunsi, K.; Karpf, A.R. PRAME expression and promoter hypomethylation in epithelial ovarian cancer. Oncotarget 2016, 7, 45352-45369. [CrossRef] [PubMed]

25. Mitsuhashi, K.; Masuda, A.; Wang, Y.H.; Shiseki, M.; Motoji, T. Prognostic significance of PRAME expression based on immunohistochemistry for diffuse large B-cell lymphoma patients treated with R-CHOP therapy. Int. J. Hematol. 2014, 100, 88-95. [CrossRef] [PubMed]

26. Ercolak, V.; Paydas, S.; Bagir, E.; Ergin, M.; Seydaoglu, G.; Celik, H.; Yavu, B.; Tanriverdi, K.; Gunaldi, M.; Afsar, C.U.; et al. PRAME Expression and Its Clinical Relevance in Hodgkin's Lymphoma. Acta Haematol. 2015, 134, 199-207. [CrossRef] [PubMed]

27. Proto-Siqueira, R.; Figueiredo-Pontes, L.L.; Panepucci, R.A.; Garcia, A.B.; Rizzatti, E.G.; Nascimento, F.M.; Ishikawa, H.C.; Larson, R.E.; Falcão, R.P.; Simpson, A.J.; et al. PRAME is a membrane and cytoplasmic protein aberrantly expressed in chronic lymphocytic leukemia and mantle cell lymphoma. Leuk. Res. 2006, 30, 1333-1339. [CrossRef]

28. Shiseki, M.; Ishii, M.; Ohwashi, M.; Wang, Y.H.; Tanaka, N.; Osanai, S.; Yoshinaga, K.; Mori, N.; Tanaka, J. High PRAME expression is associated with poor survival and early disease progression in myelodysplastic syndromes with a low bone marrow blast percentage. Leuk. Lymphoma 2021, 62, 2448-2456. [CrossRef] [PubMed]

29. Arons, E.; Suntum, T.; Margulies, I.; Yuan, C.; Stetler-Stevenson, M.; Kreitman, R.J. PRAME expression in hairy cell leukemia. Leuk. Res. 2008, 32, 1400-1406. [CrossRef]

30. Beà, S.; Salaverria, I.; Armengol, L.; Pinyol, M.; Fernández, V.; Hartmann, E.M.; Jares, P.; Amador, V.; Hernández, L.; Navarro, A.; et al. Uniparental disomies, homozygous deletions, amplifications, and target genes in mantle cell lymphoma revealed by integrative high-resolution whole-genome profiling. Blood 2009, 113, 3059-3069. [CrossRef]

31. Epping, M.T.; Hart, A.A.; Glas, A.M.; Krijgsman, O.; Bernards, R. PRAME expression and clinical outcome of breast cancer. Br. J. Cancer 2008, 99, 398-403. [CrossRef]

32. Albertsmeier, M.; Altendorf-Hofmann, A.; Lindner, L.H.; Issels, R.D.; Kampmann, E.; Dürr, H.R.; Schubert-Fritschle, G.; Angele, M.K.; Kirchner, T.; Jungbluth, A.A.; et al. Cancer Testis Antigens and Immunotherapy: Expression of PRAME Is Associated with Prognosis in Soft Tissue Sarcoma. Cancers 2020, 12, 3612. [CrossRef]

33. Tanaka, N.; Wang, Y.H.; Shiseki, M.; Takanashi, M.; Motoji, T. Inhibition of PRAME expression causes cell cycle arrest and apoptosis in leukemic cells. Leuk. Res. 2011, 35, 1219-1225. [CrossRef]

34. Radich, J.P.; Dai, H.; Mao, M.; Oehler, V.; Schelter, J.; Druker, B.; Sawyers, C.; Shah, N.; Stock, W.; Willman, C.L.; et al. Gene expression changes associated with progression and response in chronic myeloid leukemia. Proc. Natl. Acad. Sci. USA 2006, 103, 2794-2799. [CrossRef] [PubMed]

35. Al-Khadairi, G.; Decock, J. Cancer Testis Antigens and Immunotherapy: Where Do We Stand in the Targeting of PRAME? Cancers 2019, 11, 984. [CrossRef] [PubMed]

36. Gezgin, G.; Luk, S.J.; Cao, J.; Dogrusöz, M.; van der Steen, D.M.; Hagedoorn, R.S.; Krijgsman, D.; van der Velden, P.A.; Field, M.G.; Luyten, G.P.M.; et al. PRAME as a Potential Target for Immunotherapy in Metastatic Uveal Melanoma. JAMA Ophthalmol. 2017, 135, 541-549. [CrossRef]

37. Matsushita, M.; Yamazaki, R.; Ikeda, H.; Kawakami, Y. Preferentially expressed antigen of melanoma (PRAME) in the development of diagnostic and therapeutic methods for hematological malignancies. Leuk. Lymphoma 2003, 44, 439-444. [CrossRef]

38. Roszik, J.; Wang, W.L.; Livingston, J.A.; Roland, C.L.; Ravi, V.; Yee, C.; Hwu, P.; Futreal, A.; Lazar, A.J.; Patel, S.R.; et al. Overexpressed PRAME is a potential immunotherapy target in sarcoma subtypes. Clin. Sarcoma Res. 2017, 7, 11. [CrossRef]

39. Tajeddine, N.; Louis, M.; Vermylen, C.; Gala, J.L.; Tombal, B.; Gailly, P. Tumor associated antigen PRAME is a marker of favorable prognosis in childhood acute myeloid leukemia patients and modifies the expression of S100A4, Hsp 27, p21, IL-8 and IGFBP-2 in vitro and in vivo. Leuk. Lymphoma 2008, 49, 1123-1131. [CrossRef]

40. Steinbach, D.; Hermann, J.; Viehmann, S.; Zintl, F.; Gruhn, B. Clinical implications of PRAME gene expression in childhood acute myeloid leukemia. Cancer Genet. Cytogenet. 2002, 133, 118-123. [CrossRef]

41. Steinbach, D.; Viehmann, S.; Zintl, F.; Gruhn, B. PRAME gene expression in childhood acute lymphoblastic leukemia. Cancer Genet. Cytogenet. 2002, 138, 89-91. [CrossRef]

42. Greiner, J.; Schmitt, M.; Li, L.; Giannopoulos, K.; Bosch, K.; Schmitt, A.; Dohner, K.; Schlenk, R.F.; Pollack, J.R.; Dohner, H.; et al. Expression of tumor-associated antigens in acute myeloid leukemia: Implications for specific immunotherapeutic approaches. Blood 2006, 108, 4109-4117. [CrossRef] [PubMed]

43. de Masson, A.; O’Malley, J.T.; Elco, C.P.; Garcia, S.S.; Divito, S.J.; Lowry, E.L.; Tawa, M.; Fisher, D.C.; Devlin, P.M.; Teague, J.E.; et al. High-throughput sequencing of the T cell receptor $\beta$ gene identifies aggressive early-stage mycosis fungoides. Sci. Transl. Med. 2018, 10, eaar5894. [CrossRef] 